\title{
Formulasi Dan Evaluasi Sediaan Hand Body Lotion Ekstrak Biji Bunga Matahari (Helianthus annus L.)
}

\author{
Formulation And Evaluation Of Hand Body Lotion Sun Flower Seeds Extract \\ (Helianthus annus L.)
}

\author{
I.A.K Pramushinta ${ }^{1}$, P.T. Hardani ${ }^{2}$ \\ Program Studi Farmasi, Universitas PGRI Adi Buana Surabaya \\ Email: iak.pramushinta@unipasby.ac.id ${ }^{1}$, prismath@unipasby.ac.id ${ }^{2}$
}

\begin{abstract}
Abstrak
Bunga matahari (Helianthus annus L.) merupakan salah satu tanaman yang memiliki banyak manfaat. Minyak pada biji bunga matahari mengandung asam lemak tak jenuh berupa oleat dan linoleate yang lebih banyak bila dibandingkan pada minyak kedelai, kacang tanah, jagung, dan kelapa sawit. Minyak biji bunga matahari juga dilaporkan dapat digunakan sebagai bahan dasar hand body lotion. Penelitian ini bertujuan membuat formulasi Hand Body Lotion dari ekstrak Biji Bunga Matahari kemudian dilakukan evaluasi. Evaluasi yang dilakukan yaitu $\mathrm{pH}$, Homogenitas, Warna dan Bau. Hasil evaluasi $\mathrm{pH}$ didapatkan adanya perubahan $\mathrm{pH}$ masing-masing formula masih berada pada rentang pH sediaan topical 4,5-8 (SNI 16-4399-1996). Sedangkan hasil uji homogentitas yang terbaik pada formula II apabila dibandingkan pada formula I dan III disebabkan karena menggumpal pada formula I dan III. Hasil uji pada bau dan warna Hand Body Lotion tidak mengalami perubahan dengan adanya pendapat 35 responden.
\end{abstract}

Kata Kunci: Hand Body Lotion, Ekstrak Biji Bunga Matahari, Semisol

\begin{abstract}
Sunflower (Helianthus annus L.) is a plant that has many benefits. The oil in sunflower seeds contains unsaturated fatty acids in the form of oleic and linoleate morethan soybean, peanut, corn and palm oil. Sunflower seed oil is also reported to be used as a base for hand body lotions. This study aims to make a Hand Body Lotion formulation from sunflower seed extract and then evaluated. The evaluations carried out were $\mathrm{pH}$, homogeneity, color and odor. The results of $\mathrm{pH}$ evaluation showed that there was a change in the $\mathrm{pH}$ of each formula which was still in the $\mathrm{pH}$ range of the topical preparations 4.5-8 according SNI. While the best homogeneity test results in formula II when compared to formulas I and III are due to clumping in formulas I and III. The test results on the smell and color of the Hand Body Lotion did not change with the opinions of 35 respondents.
\end{abstract}

Keywords: Hand Body Lotion, Sunflower Seed Extract, Semisol

\section{PENDAHULUAN}

Bunga matahari dikenal dengan berbagai nama sun flower, pada tanaman ini memiliki nama latin Helianthus annus $L$. yang memiliki makna Heli berarti matahari dan annus adalah semusim. Bunga matahari berasal dari Meksiko dan Peru, Amerika Tengah (Ramadhani et al., 2019).

Biji bunga matahari memiliki warna keabu-abuan hijau atau hitam yang merupakan biji dari bunga matahari. Biji bunga matahari di Indonesia diolah menjadi makanan ringan seperti kuaci biji bunga matahari (Lusia, 2015). Biji bunga matahari adalah makanan yang baik dengan nilai kecukupan gizi dan dianggap sebagai makanan ringan sehat. Biji bunga matahari adalah makanan yang bagus untuk kesehatan jantung (Info perkerbunan, 2010).

Kandungan biji bunga matahari berupa protein, lemak dan karbohidrat. Sedangkan minyak biji bunga matahari memiliki kandungan asam lemak tak jenuh mencapai $91 \%$ lebih apabila dibandingkan oleat dan linoleate yang ada pada minyak kedelai, kacang tanah, jagung, dan kelapa sawit sehingga baik untuk kesehatan tubuh (Suprapto, 2009).

Menurut Rodhiyah dan Sulisiyawati (2012) pada minyak biji bunga matahari dapat mempercepat proses penyembuhan luka dikarenakan adanya kandungan zat aktif antara lain $\beta$-sitosterol, flavonoid dan asam linoleat. 
Selain digunakan sebagai sediaan sabun dan gel, biji bunga matahari juga dapat digunakan sebagai bahan dasar hand body lotion yang umumnya digunakan dalam perawatan kesehatan kulit (Paramitha et al., 2017). Hal ini didukung oleh tradisi masyarakat Indonesia yang gemar menggunakan bahan-bahan alami sebagai obat tradisional, salah satunya yaitu penggunaan minyak biji bunga matahari. Biji bunga matahari dipilih karena mengandung vitamin $\mathrm{E}$ yang dapat membantu melindungi kulit dari oksidasi sel yang merusak kulit, $\beta$ - sitosterol yang dapat membantu memproduksi melanin dan antioksidan sebagai penangkal radikal bebas (Arantika, 2018).

Hand and Body lotion merupakan produk perawatan tubuh yang digunakan untuk melembabkan dan melindungi kulit dari pengaruh lingkungan (Rusli dan Pandean, 2017).

Pada jaman milenial ini, perawatan kulit telah menjadi trend terutama bagi golongan usia produktif 17 tahun ke atas. Perawatan kulit dinilai sangat dibutuhkan untuk menjaga agar kulit tidak menjadi kering, kasar, dan kusam. Salah satu cara untuk mengatasi masalah tersebut adalah dengan menggunakan pelembab yaitu handbody lotion (Noer dan Sundari, 2016).

Hand and Body lotion yang diminati umumnya berupa produk krim yang berbentuk $\mathrm{O} / \mathrm{W}$ (minyak dalam air). Krim $\mathrm{O} / \mathrm{W}$ merupakan salah satu emulsi minyak dalam air yang memiliki bentuk menyerupai lotion yan mengandung fase minyak dan fase humektan yang lebih banyak dari lotion yaitu $15-40 \%$ fase minyak, 5-15\% humektan dan sisanya adalah fase air. Kandungan fase tersebut mudah diserap dikulit setelah digosokkan, tidak lengket, mudah mengalir dan mudah dipompa (Williams, et al., 1992).

\section{METODOLOGI}

\section{Jenis Penelitian}

Jenis penelitian yang digunakan yaitu penelitian eksperimental. Penelitian ini dilaksanakan di Laboratorium Farmasi
Universitas PGRI Adi Buana Surabaya. Metode yang digunakan adalah eksperimental laboratorium dengan menggunakan analisis deskriptif.

\section{Alat dan Bahan}

Bahan yang digunakan untuk pembuatan handbody lotion adalah etanol 96\%, Glitter Wax granul, STA, Laurex, Paraffin Liquid, Dimethicon, Bees Wax, Lanolin, Metil paraben, Propel Paraben, BHT, Emulgent, MPG, Akuades, Parfum. Alat-alat yang digunakan timbangan analitik, pengaduk, gelas ukur 5, 100, 500 $\mathrm{mL}$, gelas beker $500 \mathrm{~mL}$, botol semprot, pipet tetes, pipet skala, kertas saring.

\section{Penyiapan bahan sediaan \\ Pembuatan Ekstrak Biji Bunga Matahari}

Bahan sediaan yang digunakan adalah biji bunga matahari (Helianthus annus L.). Pembuatan ekstrak dilakukan dengan metode maserasi dengan menggunakan etanol $70 \%$ dengan perbandingan 1:1.

Menimbang biji bunga matahari sebanyak 500 g, kemudian dimasukan ke dalam wadah maserasi, tambahkan etanol 96\% dengan perbandingan 1:1, kemudian di ekstraksi dan dilakukan remaserasi berulang. Hasil esktraksi di rotavapor untuk mendapatkan esktrak kental.

\section{Pembuatan Handbody Lotion}

Formulasi pembuatan handbody lotion pada penelitian ini terdiri dari setil alcohol, asam stearate, paraffin cair, trietanolamin, propilen glikol dan aquades. Konsentrasi ekstrak biji bunga matahari yang digunakan bervariasi yaitu formulasi pertama dengan konsentrasi $0,2 \%$, formulasi kedua dengan konsentrasi $0,4 \%$ dan formulasi ketiga dengan konsentrasi $0,6 \%$. Formulasi handbody lotion biji bunga matahari dapat dilihat pada Tabel 1.

Pembuatan sediaan handbody lotion ekstrak biji bunga matahari dengan prinsip pencampuran fase minyak dengan fase air lalu dicampurkan diatas waterbath. 


\section{Uji Warna dan Bau Handbody Lotion Biji Bunga Matahari}

Uji organoleptik dilakukan dengan cara mengamati secara visual terhadap bentuk, warna, dan bau sediaan. Uji dilakukan terhadap 35 orang responden, yang sebelumnya telah melihat sediaan handbody lotion (dalam tiga formula), kemudian dilakukan penilaian kembali setelah sediaan disimpan selama 28 hari.

\section{Uji Homogenitas}

Uji homogenitas dilakukan dengan cara meletakkan sedikit handbody lotion di atas kaca objek, kemudian diamati ada tidaknya butiran-butiran kasar pada sediaan dan tercampurnya bahan aktif dan bahan tambahan pada sediaan.

\section{Uji pH}

Uji $\mathrm{pH}$ dilakukan dengan mengukur $\mathrm{pH}$ pada sediaan handbody lotion (masing-masing formula) menggunakan $\mathrm{pH}$ meter selama 28 hari penyimpanan.

Tabel 1. Formula sediaan semisol ekstrak biji bunga matahari

\begin{tabular}{|c|c|c|c|c|}
\hline \multirow[t]{2}{*}{ Bahan } & \multicolumn{3}{|c|}{ Konsentrasi \% } & \multirow[t]{2}{*}{ Fungsi } \\
\hline & F1 & F2 & F3 & \\
\hline $\begin{array}{l}\text { Ekstrak Biji Bunga } \\
\text { Matahari }\end{array}$ & 3,7 & 3,7 & 3,7 & Zat Aktif \\
\hline Setil Alkohol & 2 & 2 & 2 & Pengemulsi \\
\hline Asam stearate & 2 & 2 & 2 & Pengemulsi \\
\hline Paraffin cair & 1 & 1 & 1 & Pelembab \\
\hline Trictanolamin & 0,2 & 0,4 & 0,6 & Pengemulsi \\
\hline Propilen glikol & 3 & 3 & 3 & Pelembab \\
\hline Aquades & 100 & 100 & 100 & Pembawa \\
\hline
\end{tabular}

\section{HASIL DAN PEMBAHASAN}

\section{Hasil uji pH Hand Body Lotion Ekstrak Biji Bunga Matahari}

Formulasi hand body lotion ekstrak biji bunga matahari dalam penelitian ini terdiri dari 3 formula yaitu $0,2 \%, 0,4 \%$,
$0,6 \%$. Hasil ekstrak biji bunga matahari dapat dilihat dalam Tabel 2.

Tabel 2. Hasil uji pH Hand Body yang mengandung Ekstrak Biji Bunga Matahari selama 28 hari penyimpanan

\begin{tabular}{|c|c|c|c|c|c|c|}
\hline \multirow{2}{*}{$\begin{array}{l}\text { Hand Body } \\
\text { Lotion }\end{array}$} & \multicolumn{5}{|c|}{ pH pada hari ke- } & \multirow{2}{*}{$\begin{array}{c}\text { Keterangan } \\
\text { (pH memenuhi syarat } \\
\mathbf{4 , 5 - 8})\end{array}$} \\
\hline & 0 & 7 & 14 & 21 & 28 & \\
\hline Formula I & 5,83 & 5,91 & 5,87 & 5,93 & 5,82 & MS \\
\hline Formula II & 6,31 & 6,45 & 6,35 & 6,52 & 6,63 & MS \\
\hline Formula III & 5,94 & 5,79 & 5.70 & 5,63 & 5,76 & MS \\
\hline
\end{tabular}

Keterangan: MS: Memenuhi syarat

Berdasarkan hasil pengukuran $\mathrm{pH}$ Hand Body Lotion yang mengandung Ekstrak Biji Bunga Matahari selama 28 hari penyimpanan pada Tabel 2 didapatkan rentang $\mathrm{pH}$ formula I yaitu 5,82-5,93, $\mathrm{pH}$ formula II 6,31-6,63, pH formula III 5,635,94. Dilihat pada Tabel 2 pada $\mathrm{pH}$ ketiga formula mengalami kenaikan dan 
penurunan. $\mathrm{pH}$ ini seharusnya mengalami kenaikan linier. Secara keseluruhan merupakan hasil dari pengukuran $\mathrm{pH}$ menunjukkan bahwa setiap formula terjadi penurunan nilai $\mathrm{pH}$ selama penyimpanan karena sifat dari ekstrak yang memiliki kandungan asam. Perubahan $\mathrm{pH}$ masingmasing formula masih berada pada rentang
$\mathrm{pH}$ sediaan topical 4,5-8 (SNI 16-43991996). Hal ini juga dilaporkan oleh Noer dan Sundari (2016) yang melakukan formulasi handbody lotion dari ekstrak buah naga, didapatkan uji $\mathrm{pH}$ yang tidak linier namun perubahan $\mathrm{pH}$ yang terjadi masih memenuhi persyaratan sesuai SNI untuk sediaan topical.

Tabel 3. Hasil Uji pH Handbody Lotion yang mengandung Ekstrak Biji Bunga Matahari selama 28 Hari Penyimpanan

\begin{tabular}{|c|c|c|c|c|c|c|}
\hline \multirow{2}{*}{$\begin{array}{l}\text { Hand Body } \\
\text { Lotion }\end{array}$} & \multicolumn{5}{|c|}{ pH pada hari ke- } & \multirow{2}{*}{$\begin{array}{c}\text { Keterangan } \\
\text { (syarat homogen) }\end{array}$} \\
\hline & 0 & 7 & 14 & 21 & 28 & \\
\hline Formula I & $\mathrm{TH}$ & $\mathrm{TH}$ & $\mathrm{TH}$ & $\mathrm{TH}$ & $\mathrm{TH}$ & TMS \\
\hline Formula II & $\mathrm{H}$ & $\mathrm{H}$ & $\mathrm{H}$ & $\mathrm{H}$ & $\mathrm{H}$ & MS \\
\hline Formula III & TH & TH & TH & $\mathrm{TH}$ & TH & TMS \\
\hline
\end{tabular}

Keterangan: H: Homogen; TH: Tidak homogen; MS: Memenuhi Syarat; TMS: Tidak memenuhi syarat

Hasil pengamatan terhadap homogenitas Handbody Lotion yang mengandung ekstrak Biji Bunga Matahari selama 28 hari penyimpanan Handbody lotion dioleskan sedikit pada kaca objek, kemudian diamati ada tidaknya butiranbutiran kasar. Pada formula I dan formula III tampak tidak homogen dikarenakan ada bintik-bintik putih yang menggumpal.

Bintik-bintik putih ini kemudian dilihat secara mikroskopik dengan pembesaran 40x10 terdapat penggumpalan partikel. Penggumpalan ini dapat diakibatkan oleh aerosol yang tidak tercampur pada saat awal pembuatan handbody lotion. Hal ini belum terjadinya proses penyabunan yang sempurna pada saat pembuatan handbody lotion. Aerosil sendiri memiliki sifat berbentuk granul dan amorf, dimana seharusnya aerosil digerus terlebih dahulu lalu diayak dan ditambahkan sedikit demi sedikit pada basis lotion.

Selain itu, homogenitas pada suatu system emulsi dipengaruhi oleh teknik pencampuran yang dilakukan serta alat yang digunakan pada proses pembuatan emulsi tersebut (Noer dan Sundari, 2016).

Tabel 4. Hasil Pengamatan Perubahan Warna Hand Body Lotion yang mengandung Ekstrak Biji Bunga Matahari selama 28 Hari Penyimpanan

\begin{tabular}{lcccc}
\hline \multicolumn{1}{c}{ Hand Body } & \multicolumn{2}{c}{ Hasil } & \multicolumn{2}{c}{ Presentase } \\
\cline { 2 - 5 } \multicolumn{1}{c}{ Lotion } & Berubah & Tidak Berubah & Berubah & Tidak Berubah \\
\hline Formula I & 0 & 35 & $0 \%$ & $100 \%$ \\
\hline Formula II & 0 & 35 & $0 \%$ & $100 \%$ \\
\hline Formula III & 0 & 35 & $0 \%$ & $100 \%$ \\
\hline
\end{tabular}

Hasil penelitian tentang adanya perubahan warna digunakan sebagai uji kualitas fisik pada Hand Body Lotion secara organoleptik. Uji warna dilakukan terhadap
35 orang responden. Responden diminta untuk terlebih dahulu melihat warna handbody lotion untuk masing-masing formula, kemudian diminta untuk mengisi 
angket kuesioner yang telah disediakan. Uji warna dikelompokan menjadi dua kategori yaitu berubah dan tidak berubah. Untuk Uji bau dilakukan metode yang sama dengan uji warna.

Dari hasil uji warna dan bau pada penelitian ini, setelah dilakukan pengamatan didapatkan hasil pada masing-masing formula handbody lotiontidak terjadi perubahan warna. Sedangkan hasil dari kuisioner dapat dilihat pada Tabel 4 dan 5, dimana masing-masing formula tidak mengalami perubahan warna dan bau selama 28 Hari penyimpanan.

Tabel 5. Hasil Pengamatan Perubahan Bau Hand Body Lotion yang mengandung Ekstrak Biji Bunga Matahari selama 28 Hari Penyimpanan

\begin{tabular}{lcccc}
\hline \multicolumn{1}{c}{ Hand Body } & \multicolumn{2}{c}{ Hasil } & \multicolumn{2}{c}{ Presentase } \\
\cline { 2 - 5 } \multicolumn{1}{c}{ Lotion } & Berubah & Tidak Berubah & Berubah & Tidak Berubah \\
\hline Formula I & 0 & 35 & $0 \%$ & $100 \%$ \\
\hline Formula II & 0 & 35 & $0 \%$ & $100 \%$ \\
\hline Formula III & 0 & 35 & $0 \%$ & $100 \%$ \\
\hline
\end{tabular}

\section{KESIMPULAN DAN SARAN}

Dari penelitian ini dapat disimpulkan bahwa pada:

1. Uji $\mathrm{pH}$ handbody lotion ekstrak biji bunga matahari, terjadi perubahan $\mathrm{pH}$ setelah 28 hari penyimpanan, namun masih berada pada rentang $\mathrm{pH}$ sediaan topical 4,5-8 (SNI 16-4399-1996).

2. Uji homogenitas didapatkan hasil yang homogeny pada formula II, sedangkan pada formula I dan III masih tidak memenuhi syarat dikarenakan ada bitnik-bintik putih yang menggumpal.

3. Hasil uji perubahan warna dan perubahan bau tidak mengalami perubahan dengan pendapat dari 35 orang responden.

\section{UCAPAN TERIMA KASIH}

Terimakasih terhadap pihak-pihak yang telah membantu atas berjalannya penelitian ini.

\section{REFERENSI}

Arantika, Oki. 2018. Pengaruh Proporsi Biji Bunga Matahari (Helianthus annuus L.) dan Bunga Kenanga (Cananga odorata) terhadap Sifat Fisik Masker Tradisional. E-Journal Volume 07 Nomor 1, pp. 92-98.

Info perkebunan.2010. [Online] Available at:

perkebunan.litbang.pertanian.go.id
Lusia Anggraeni., Wiryatun L., Susetyowati. 2015. Asupan gizi dan status gizi vegetarian pada komunitas vegetarian di Yogyakarta. Jurnal Gizi Klinik Indonesia, 11(4), pp. 143-149.

Noer dan Sundari. 2016. Formulasi Hand And Body Lotion Ekstrak Kulit Buah Naga Putih (Hylocereus undatus) dan Uji Kestabilan Fisiknya. Jurnal Kesehatan. Volume XI No. 1, pp.102-113.

Paramitha., D.A., James S, dan Ni Made S. 2017. Sifat Fisikokimia Hand and Body Lotion dengan Pemanfaatan Ekstrak Etanol Bunga Gemitir (Tagetes Erecta L.) dan Bunga Pacar Air Merah (Impatiens Balsamina L.,) dari Limbah Canang, Cakra Kimia Indonesia E-Journal of Applied Chemistry. Vol 5 No 1.

Ramadhani, T., A., dkk. 2019. Pannacotta Biji Bunga Matahari (Helianthus Annus L.) bagi Vegetarian. HEJ (Home Economics Journal) Vol 3 No 2 hal 38-61.

Rodhiyah dan Sulistiyawati. 2012. Pengaruh Ekstrak Minyak Biji Bunga Matahari (Helianthus annuus) Terhadap Proses Penyembuhan Luka. Prosiding Seminar Nasional IX Pendidikan Biologi FKIP UNS: 706711. 
Rusli dan Pandean. 2017. Formulasi Hand and Body Lotion Antiokskidan Ekstrak Daun Muda Jambu Mete (Anacardium ocidentale L.). Warta Farmasi, 6(1), pp. $57-64$.

Suprapto dan Supanjani, 2009, Analisis genetik kuantitatif dan kompatibilitas sendiri dan bunga matahari di lahan ultisol, Vol 12 No 1. Universitas Bengkulu. Bengkulu
Williams, D.F., and Schmitt, W.H. 1992. Chemistry and Technology of Cosmetics and Toiletries Industry. London: Blackie Academic and Professional. 